\title{
Removal of Textile Dyes Present in Effluents by Adsorption in Polyurethane Foams Derived from Vegetable Oil
}

\author{
Daniel Henrique Rattis Lemos, Carmen Aparecida Cardoso Maia Camargo, \\ Marcio Antonio Ferreira Camargo \\ Academic Unit of Passos, University of State of Minas Gerais, Passos, Brazil \\ Email:danielrattis@hotmail.com,kkcamargo@yahoo.com.br, mcamargo2004@yahoo.com.br
}

How to cite this paper: Lemos, D.H.R., Camargo, C.A.C.M. and Camargo, M.A.F. (2019) Removal of Textile Dyes Present in Effluents by Adsorption in Polyurethane Foams Derived from Vegetable Oil. Open Access Library Journal, 6: e5481.

https://doi.org/10.4236/oalib.1105481

Received: May 20, 2019

Accepted: June 3, 2019

Published: June 6, 2019

Copyright $\odot 2019$ by author(s) and Open Access Library Inc.

This work is licensed under the Creative Commons Attribution International License (CC BY 4.0).

http://creativecommons.org/licenses/by/4.0/

\section{(c) (i) Open Access}

\begin{abstract}
Large amounts of effluents, some even untreated, used in the dyeing industries are dumped into natural water provoking a huge environmental impact daily. The Analytical Chemistry and Polymer Technology Group from the University of Sao Paulo in Sao Carlos, Brazil developed the polyurethane foam. It is a unique type of foam produced from vegetable oil-a renewable natural raw material. The objective of the research was to verify the effectiveness of adsorption of textile dyes in effluents through the polyurethane foam derived from vegetable oil. The dye samples collected from an industry in the dying segment in the city of Passos, Minas Gerais State, Brazil, were prepared in various predetermined concentrations. The percolation in thermostatic glass column containing polyurethane foam derived from vegetable oil was used as analytical method, with known mass, pressed in the form of powder between two solid foam disks containing two millimeters of thickness.
\end{abstract}

\section{Subject Areas}

Analytical Chemistry, Environmental Chemistry, Public Health

\section{Keywords}

Polyurethanes, Adsorption, Percolation, Vegetable Oil

\section{Introduction}

The polyurethane foam obtained from vegetable oil is the foam differentiated from those that usually exist in the market, because the raw material is biodegradable, reducing environmental impact [1]. The polymerization of urethanes 
occurs during the synthesis of polyurethane foams due to the reaction of a compound with two or more isocyanates with a polyol [2].

Ferreira (2006) [3] demonstrated the effectiveness of polyurethane foams, modified by the addition of sulfur powder and zinc oxide, as a practical filtering system and efficient for the removal of mercury and sulfur compounds from natural gas. The author also said that the polyurethane foams have their own characteristics that allow the passage of gas as open cells and a good homogeneity and pore distribution.

Textile dyes are organic compounds that impregnate the textile substrate fibers with different color during the dyeing process. Most effluents from the textile industry come from the dyeing stages, resulting in the degradation of the environment, because the dyes are resistant to biological treatments and have slow degradation kinetics [4] (Trombini and Doi, 2012).

The polluting potential of a small/medium-sized textile industry is estimated to be equivalent to the volume of waste generated by approximately 7000 to 20,000 people, according to (Moraes, Freire, Durán, 2000, p. 369 and Pereira, Freire, 2005, p. 131) [5]. Guaratini and Zanoni (2000) [6] add that due to their own nature, dyes are highly detectable to naked eyes and are visible in some cases even at concentrations as low as $1 \mathrm{ppm}(1 \mathrm{mg} / \mathrm{L})$. Indeed, a small amount of dye released into aquatic effluents can color the rivers and be easily detected by the public and authorities. The dyes can interfere in the process of photosynthesis in the rivers with huge impact to the environment [7].

Since this is an unpublished study, no papers were found where polyurethane foams derived from vegetable oils were used in the adsorption of textile dyes. It was observed that the effectiveness of polyurethane foams obtained from vegetable oil for the adsorption of textile dyes is an excellent viable alternative to avoid the contamination of textile dyes in the aquatic environment.

\section{Materials and Methods}

Randomly, the choice of dyes was not restricted to any criterion such as color, hue and solubility, and there was only restriction regarding the physical state that in this context was delimited to dyes in the solid state because they are more stable and with less potential of sample degradation. It was collected water samples from the Effluent Treatment Station of a company founded in 1984 in the city of Passos, state of Minas Gerais in Brazil that uses industrial dyeing.

The dyes available for sampling belonged to the line of direct dyes because they are economically feasible and easy to apply, as well as used in different types of fabric. Thus, five different samples were selected: Green Quimacel Concentrated Light, Violet Quimacel Light B, Rubinol Quimacel Light BL, Yellow Quimacel Light GL and Orange Quimacel Light 2G 250. The international registrations of these dyes are Green-1, Violet-51, Red-83, Yellow-86 and Orange-39, respectively.

The dyes were prepared in aqueous solution. Due to the high solubility, the 
solution was then prepared with concentrations close to $1 \mathrm{~mol} \cdot \mathrm{L}^{-1}, 2 \mathrm{~mol} \cdot \mathrm{L}^{-1}, 3$ $\mathrm{mol} \cdot \mathrm{L}^{-1}, 4 \mathrm{~mol} \cdot \mathrm{L}^{-1}$ and $5 \mathrm{~mol} \cdot \mathrm{L}^{-1}$.

\subsection{Reagents and Solutions}

Stock solutions $1000 \mathrm{mg} \cdot \mathrm{L}^{-1}$ of dyes provided by the company were prepared by being dissolved in distilled water. Subsequently, the standard solutions were prepared by successively diluting at concentrations close to $1 \mathrm{~mol} \cdot \mathrm{L}^{-1}, 2 \mathrm{~mol} \cdot \mathrm{L}^{-1}$, $3 \mathrm{~mol} \cdot \mathrm{L}^{-1}, 4 \mathrm{~mol} \cdot \mathrm{L}^{-1}$ and $5 \mathrm{~mol} \cdot \mathrm{L}^{-1}$. All reagents of analytical grade were used without prior purification. The stock solutions were stored in the refrigerator in amber glass bottles for a maximum of three weeks, later they were properly discarded.

The analytical solutions used were subsequently prepared from the dilution of the stock solutions in volumetric flask, the volume being filled with distilled water in a mixed bed column.

Polyurethane foam was made and supplied by the Group of Analytical Chemistry and Polymer Technology_GQATP of the Institute of Chemistry of São Carlos-IQSC/USP [8].

The polyurethane was prepared by mixing the prepolymer and the polyol. The stoichiometric ratio for the polyurethane is 1:0.7 (prepolymer and polyol, respectively).

After curing, the polyurethane has approximately a specific mass of 0.0440 $\mathrm{g} / \mathrm{cm}^{3}$ and a pore size equal to $0.7 \mu \mathrm{m}$.

\subsection{Storage of Solutions and Effluent}

Amber glass vials were used during the experiments. They are kept in a refrigerator at a temperature of approximately $12.0^{\circ} \mathrm{C} \pm 0.2^{\circ} \mathrm{C}$ to prevent the decomposition of the dyes by the action of light, as well as variations in the concentration caused by the evaporation of the solvent.

\subsection{Adsorption of Dyes}

The amount of adsorption of dyes present in water was done by percolation in a thermostatted glass column. The results are shown in Figure 1. The polyurethane, with a known mass, was pressed in the form of powder between two solid foam disks containing two millimeters thick and $20 \mathrm{~mm}$ in diameter. $50 \mathrm{~mL}$ of sample was used for elution.

\subsection{UV/V Is Absorption Spectrophotometry}

The quantitative determinations of the dyes before and after percolation in the column containing the polyurethane foam, through UV/V is Spectrophotometry measurements uses quartz cuvettes of $1 \mathrm{~cm}$ optical path and deionized water as a reference.

The intensity in color of dye solution was calculated using the Lambert-Beer Law shown in Equation (1). A relation between absorbance, sample thickness 


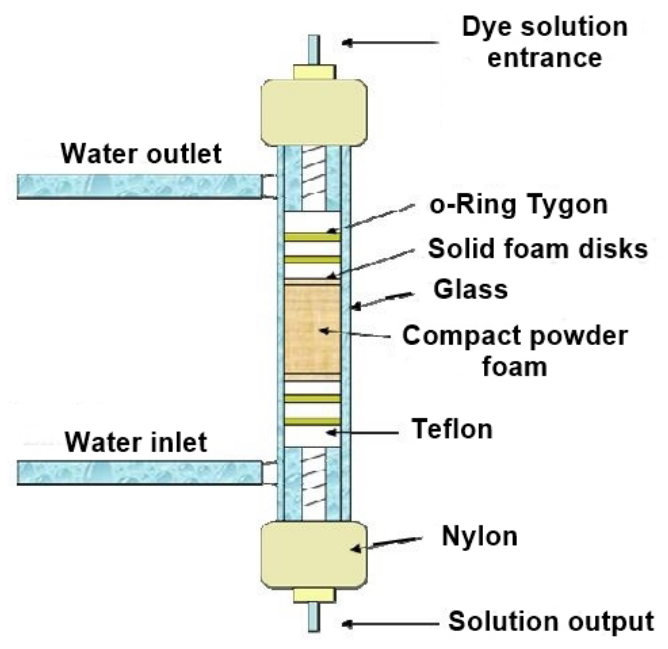

Figure 1. Thermostatted glass column used in the experiment. Source: Camargo, M.A.F., 2010 [8].

(optical path) and concentrations of the species they absorb was established.

$$
A=\varepsilon b c
$$

where $c$ is the concentration of the sample $\left(\mathrm{mols} \cdot \mathrm{L}^{-1}\right), \mathrm{b}$ the optical path (in centimeters) and $\varepsilon$ (epsilon) as molar absorptivity (in $\mathrm{L} \cdot \mathrm{mol}^{-1} \cdot \mathrm{cm}^{-1}$ ) [2].

Scanning measurements were performed at wavelengths of $300 \mathrm{~nm}$ to $900 \mathrm{~nm}$ at $1 \mathrm{~nm}$ intervals, with a maximum wavelength around $464 \mathrm{~nm}$ in the visible region expected, other wavelengths will be used depending on the type of dye provided for the experiments. Adsorption of the dyes in the polyurethane foam was monitored at the following wavelengths, Green-1 at $616 \mathrm{~nm}$, Violet-51 at 546 $\mathrm{nm}$, Yellow-86 at $634 \mathrm{~nm}$, Red-83 at $643 \mathrm{~nm}$ and Orange at $399 \mathrm{~nm}$, respectively. The measuring equipment was a UV-Vis Spectrophotometer, model Spectro Direct, Lovibond brand. The quantification was performed before and after elution in the foam, extending the measurement after passage through the foam for a period of 45 days in order to verify the stability of the dye in solution. The data collected in the tests were analyzed, seeking to verify the adsorption of textile dyes in polyurethane foams derived from vegetable oil.

\section{Results and Discussions}

Reliable results led to serial dilution of stock solutions until the absorbance value was less than or equal to 1 . All serial dilutions started from the stock solution dyes with the lowest concentration (Figure 2). Three levels of concentrations were chosen, high, medium and low.

Absorbance readings were performed after each further elution until the foam saturated, i.e., ceased to adsorb the dye in solution.

The potential of hydrogen $(\mathrm{pH})$ of the samples, seen in Figure 3, is an important parameter and was measured with the aim of characterizing each one of the dyes.

Note that, on average, Violet-51, Yellow-86 and Orange-39 dyes did not 


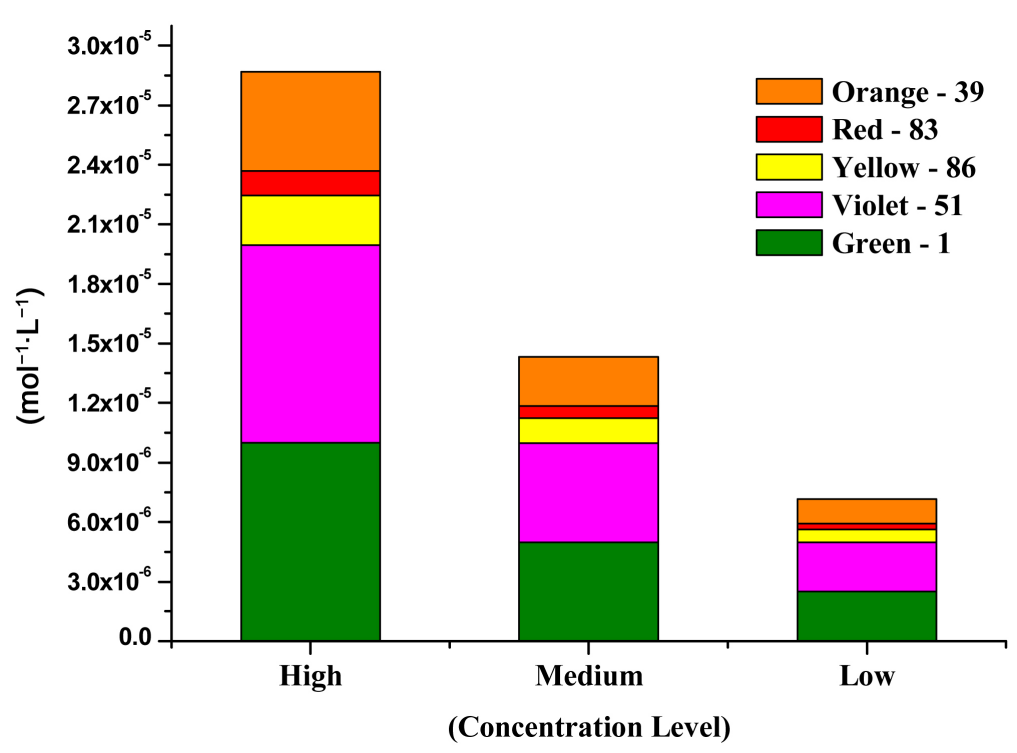

Figure 2. High, medium and low concentrations of dye solutions used in the experiment.

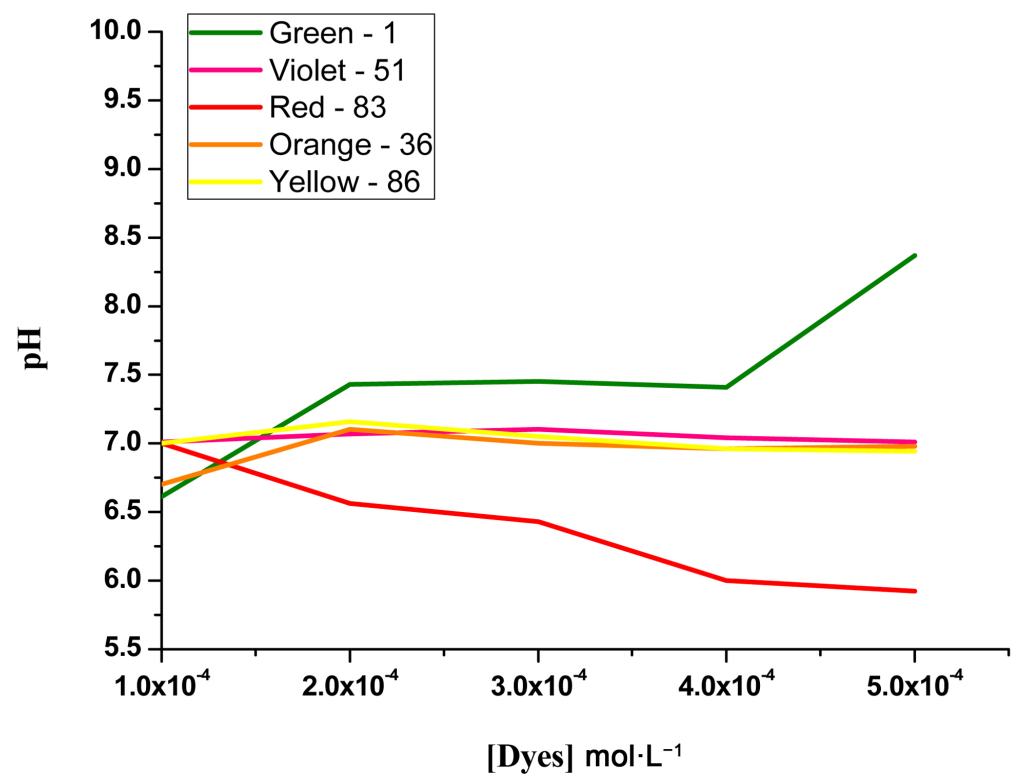

Figure 3. $\mathrm{pH}$ curves of the selected dyes.

present great oscillations of the $\mathrm{pH}$ with the increase of the concentrations, remaining close to the average $\mathrm{pH}$ value.

The Green-1 dye presented a basic character with increased concentration, while the Red- 83 presented acidic character.

\subsection{Adsorption by Glass Column Percolation and Reading by UV/Vis Spectrophotometry}

\subsubsection{Green-1}

With an average molar absorptivity of $5422 \mathrm{~L} \cdot \mathrm{mol}^{-1} \cdot \mathrm{cm}^{-1}$, the Green-1 dye had the best adsorption among all dyes presenting better variations, where there was 
a considerable difference between initial measurement and saturation measurement.

At high concentration (Figure 4), the variation was $0.296 \mathrm{~nm}$ units of absorbance, while at medium concentration (Figure 5), it was $0.068 \mathrm{~nm}$ and at low concentration (Figure 6), it was $0.015 \mathrm{~nm}$. This shows that the more solute in the solution, the greater the adsorption of these dyes.

As it is shown in Figure 6, it took the low concentration 5 elutions to saturate the foam, since after the fifth elution, the absorbance remained the same. Whereas it took the low concentration 3 elutions to saturate, maintaining the absorbance in $0.124 \mathrm{~nm}$ after other elutions.

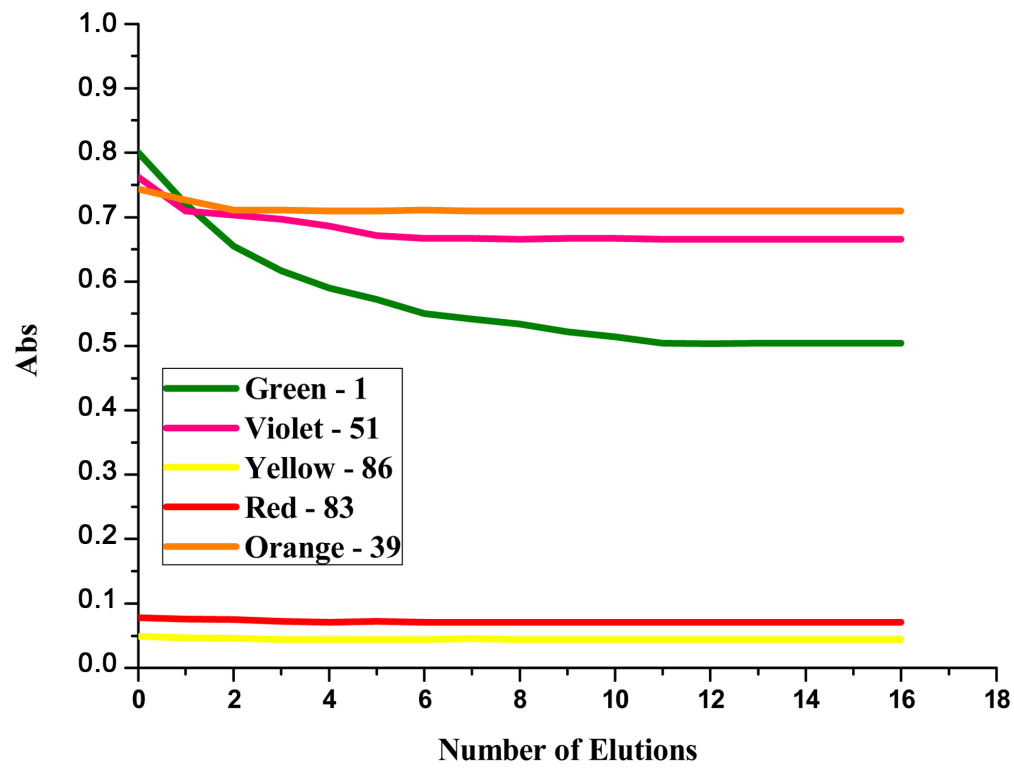

Figure 4. Dye adsorption at high concentrations.

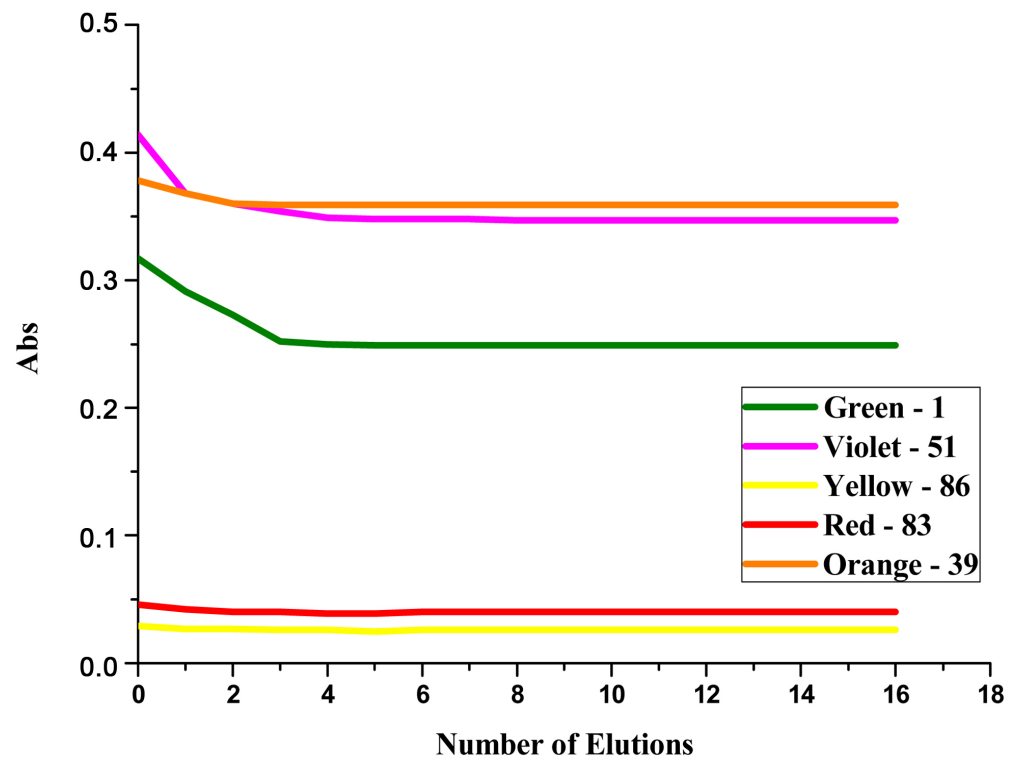

Figure 5. Dye adsorption at medium concentration. 


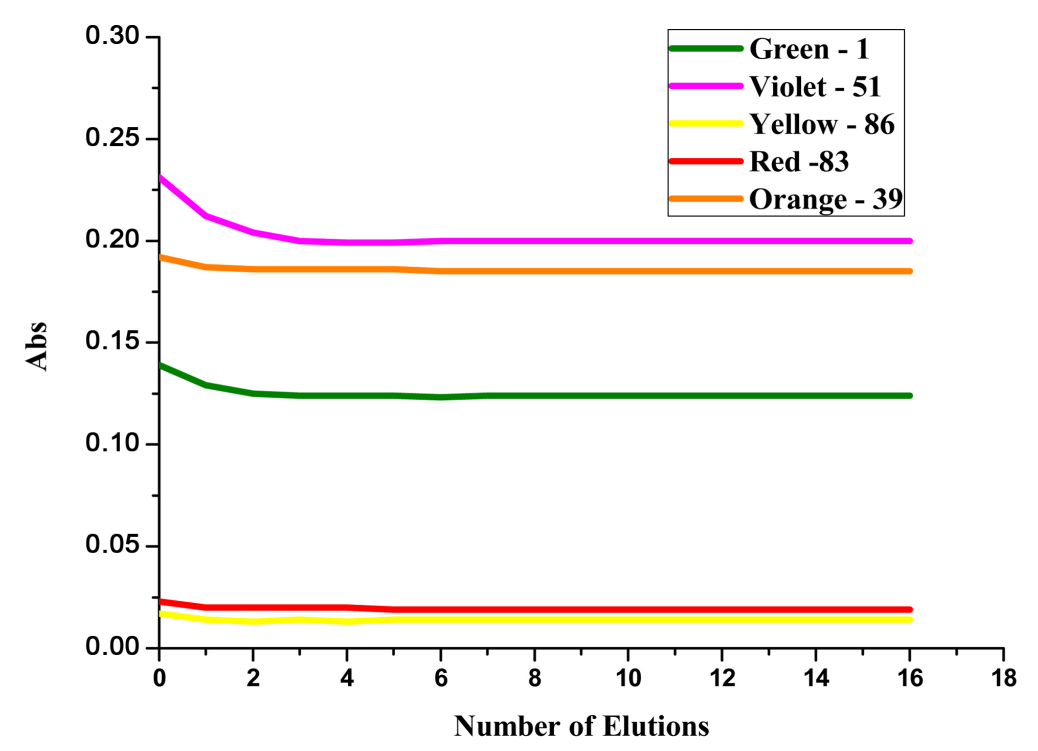

Figure 6. Dye adsorption at low concentration.

\subsubsection{Violet-51}

Violet-51 and Green-1 dyes were the only dyes where the stock solution 1, the lowest concentration, did not require dilution to obtain a high concentration in the spectra reading and adsorption percolation assays. All other dyes required at least one dilution.

The three concentrations of Violet-51 presented regular results when adsorbed, with $0.096 \mathrm{~nm}$ for high concentration; $0.067 \mathrm{~nm}$ for medium concentration and $0.031 \mathrm{~nm}$ for low concentration. All concentrations obtained considerable removal variations, taking into account the initial concentration of the sample, taking $7362 \mathrm{~L} \cdot \mathrm{mol}^{-1} \cdot \mathrm{cm}^{-1}$ of molar absorptivity.

The saturation and stabilization of the foam at medium and low concentrations occurred at elutions 4 and 5, respectively, where, it was observed that, at these elutions the absorbances were maintained.

\subsubsection{Yellow- 86}

Yellow-86 proved to be a difficult substance to manipulate for both weighing and reading its spectrum. This is due to the high molecular dye weight, complicating the weighing in the preparation of the stock solutions and later, in the UV/Vis Spectrophotometry reading, where several serial dilutions were necessary for the absorbance to reach reliable values.

The least adsorbed dye was Yellow-86, presenting $2037 \mathrm{~L} \cdot \mathrm{mol}^{-1} \cdot \mathrm{cm}^{-1}$ molar absorptivity. At high concentration it obtained a variation of absorbance of only $0.005 \mathrm{~nm}$, while at medium and low concentrations it showed $0.003 \mathrm{~nm}$. This also presented fast foam saturation, since in the highest concentration it took 4 elutions and in the lower 1 elution. At low concentration, 3 elutions were required for saturation.

\subsubsection{Red- 83}

Red-83 has a slightly lower molecular weight than Yellow-86, but still a high 
molecular weight and thus required serial dilutions to lower the concentration, being the dye that required a very high concentration lower than the others, reaching $1 / 32$.

It had a molar absorbance of $6279 \mathrm{~L} \cdot \mathrm{mol}^{-1} \cdot \mathrm{cm}^{-1}$. This dye also did not show a good adsorption, however it presented better than the worst dye, the Yellow-86. The absorbance variations expressed by the concentrations were $0.007 \mathrm{~nm}, 0.006$ $\mathrm{nm}$ and $0.003 \mathrm{~nm}$, respectively.

Also in similarity to the aforementioned dye, this also presented fast foam saturation, which one can speculate that the fast saturation of the foam would be correlated with the molecular weight.

While at high concentration, four elutions were required for the foam saturation, at medium concentration only 2 elutions were required, which was stabilized with an absorbance of $0.040 \mathrm{~nm}$. At low concentration the foam saturated with only one elution with the absorbance remaining at $0.020 \mathrm{~nm}$ after further elutions.

\subsubsection{Orange-39}

Unlike the two dyes mentioned above: the Yellow-86 and the Red-83, the Orange-39 dye is the least dense, having the lowest molecular weight of the dyes in this study. This made the manipulation for the preparation of solutions and also for the realization of the reading of its spectrum easier, not requiring several serial dilutions.

With a molar absorptivity of $14,504 \mathrm{~L} \cdot \mathrm{mol}^{-1} \cdot \mathrm{cm}^{-1}$, Orange-39 dye had absorbance change at its first concentration of $0.034 \mathrm{~nm}$, whereas at medium concentration the foam saturated with an absorbance of $0.019 \mathrm{~nm}$ and at low concentration with 0.007 nm, as shown in Figures 4-6.

\subsection{Analysis of the Gross Effluent}

The collected effluent sample had a black color (Table 1), unpleasant odor and basic character, with a $\mathrm{pH}$ of 7.05. This is due to the mixture of soap, bleaches, softeners and of course, dyes. It was chosen to collect the dye without any kind of treatment, so it was collected from the first treatment pool.

In Figure 7, it was observed excellent adsorption of dye results present in the effluent, since there was a reduction of $0.508 \mathrm{~nm}$ in absorbance. This represents $50.95 \%$ of the amount of material removed from the effluent, making the results even more relevant when taking into account that the effluent is the amount of substances and dyes mixed.

\section{Conclusions}

It is concluded that polyurethane foam derived from vegetable oil is a viable solution for the reduction of textile dyes dispensed daily by the industries, as it presented excellent adsorption results, removing the dyes even when they were in extremely low concentrations. 
Table 1. Absorbance values in textile effluent.

\begin{tabular}{cl}
\hline \multicolumn{3}{c}{ Absorbance $\left(\lambda_{\max }: 341 \mathrm{~nm}\right)$} \\
\hline No. of Elutions & $(\mathrm{nm})$ \\
\hline Initial value & 0.997 \\
1 & 0.870 \\
2 & 0.798 \\
3 & 0.701 \\
4 & 0.668 \\
5 & 0.605 \\
6 & 0.569 \\
7 & 0.512 \\
8 & 0.489 \\
9 & 0.489 \\
10 & 0.488 \\
11 & 0.489 \\
\hline
\end{tabular}

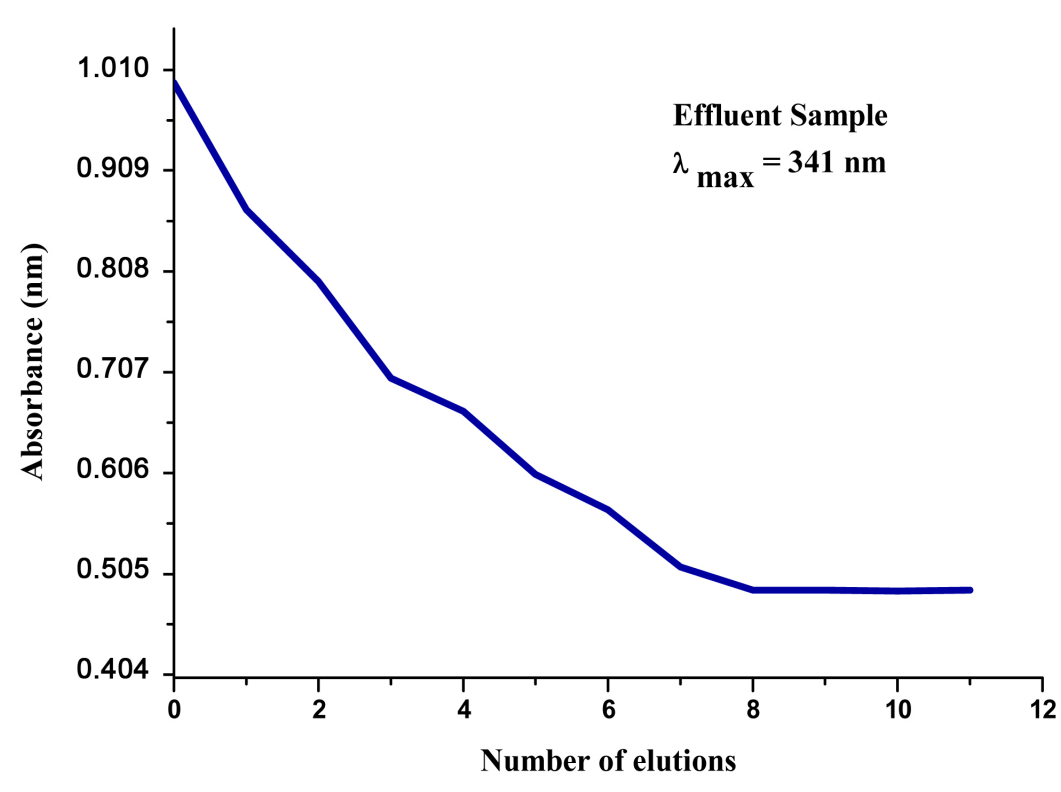

Figure 7. Adsorption curve of the untreated effluent at unknown concentration.

The results were satisfactory in the analysis of crude effluent, since this one showed reduction in the amount of dyes present in the sample. This result is still more relevant when one considers that the raw effluent sample is a mixture of various dyes.

This biodegradable foam obtained from renewable sources coupled to the principal receptor pipeline of the Effluent Treatment Station of the industries would considerably reduce the costs of treatments for the dye removal used in the various areas of dyeing as well as the reduction of physical space due to the dispensability of more pools for such treatments reducing thus the aggression to the environment. 


\section{Conflicts of Interest}

The authors declare no conflicts of interest regarding the publication of this paper.

\section{References}

[1] Ereno, D. (2003) Próteses de mamonas. Revista Pesquisa-Fapesp. http://revistapesquisa.fapesp.br/2003/09/01/proteses-de-mamona/

[2] Cangemi, J.M. (2006) Biodegradação de poliuretano derivado do óleo de mamona. Tese (Doutorado em Ciências), Instituto de Química de São Carlos, Universidade de São Paulo, São Carlos, 142 p.

http://www.teses.usp.br/teses/disponiveis/75/75132/tde-26042007-091940/pt-br.php

[3] Ferreira, R.S. (2006) Desenvolvimento de materiais poliméricos uretânicos para purificação de gás natural: remoção de mercúrio e compostos à base de enxofre. Dissertação (Mestrado em Química), Curso de Pós-Graduação em Química, Setor de Ciências Exatas, Universidade Federal do Paraná, Paraná, 80 p. https://acervodigital.ufpr.br/bitstream/handle/1884/7275/DISSERTA\%C3\%87\%C3 \%83O\%20DE\%20MESTRADO_FERREIRA_RODRIGO\%20SOARES.pdf?sequence $=1$ \&isAllowed $=\mathrm{y}$

[4] Trombini, R.B. and Doi, S.M.O. (2012) Remoção de cor e análises físico-química de efluentes de indústrias têxteis tratados com Ganoderma spp. Revista Fapciência, 9, 101-122. http://www.cesuap.edu.br/fap-ciencia/edicao_2012/012.pdf

[5] Pereira, W.S. and Freire, R.S. (2005) Ferro zero: Uma nova abordagem para o tratamento de águas contaminadas com compostos orgânicos poluentes. Química Nova, 28, 130-136.

http://quimicanova.sbq.org.br/imagebank/pdf/Vol28No1_130_21-DV04091.pdf https://doi.org/10.1590/S0100-40422005000100022

[6] Guaratini, C.C.I. and Zanoni, M.V.B. (2000) Corantes têxteis. Química Nova, 23, 71-78. http://www.scielo.br/pdf/qn/v23n1/2146.pdf https://doi.org/10.1590/S0100-40422000000100013

[7] Catanho, M., Malpass, G.R.P. and Motheo, A.J. (2006) Avaliação dos tratamentos eletroquímico e fotoeletroquímico na degradação de corantes têxteis. Química Nova, 29, 983-989. http://www.scielo.br/pdf/qn/v29n5/31061.pdf https://doi.org/10.1590/S0100-40422006000500018

[8] Camargo, M.A.F. (2010) Espumas poliuretânicas derivadas de óleo de mamona utilizadas na adsorção de bifenilaspolicloradas (PCBs) presentes em óleo mineral isolante. Tese (Doutorado em Química Analítica), Instituto de Química de São Carlos, Universidade de São Paulo, São Carlos.

http://www.teses.usp.br/teses/disponiveis/75/75132/tde-23032011-164847/pt-br.php 